The digestive tract development of the tiger grouper ... (Ahmad Muzaki)

\title{
THE DIGESTIVE TRACT DEVELOPMENT OF THE TIGER GROUPER Epinephelus fuscoguttatus LARVAE TREATED WTH THYROXINE HORMONE
}

\author{
Ahmad Muzaki\#, Ketut Mahardika, Indah Mastuti, Wawan Andriyanto, \\ Yasmina Nirmala Asih, and Ida Komang Wardana \\ Research and Development Institute for Mariculture, Gondol, Bali
}

(Received 15 May 2012; Accepted 17 September 2012)

\begin{abstract}
Thyroxin administration in tiger grouper larval rearing was conducted to determine its effect on development of digestive tract of the larvae. Newly hatched larvae were treated with $0 \mathrm{mg} / \mathrm{L}$ (control), $0.1 \mathrm{mg} / \mathrm{L}$, and $0.2 \mathrm{mg} / \mathrm{L}$ of thyroxin for 2 hours in a $30 \mathrm{~L}$ tank before were transferred into a $1 \mathrm{~m}^{3}$ rearing tank. Samples were collected daily until $10 \mathrm{DAH}$ and every 3 days until $40 \mathrm{DAH}$. Development of digestive tract was observed using histological method. For all treatments, the digestive tract was the same on $1 \mathrm{DAH}$ and $2 \mathrm{DAH}$. The digestive tract of $1 \mathrm{DAH}$ larvae was still closed and still in the form of a simple tube. The mouth, buccopharynx, liver, pancreas, and rectum were found on $2 \mathrm{DAH}$. On $3 \mathrm{DAH}$, the esophagus, stomach, intestines, and anus started to develop. At this stage, the digestive tract of larvae treated with and without thyroxin started to become distinguishable. Several goblet cells were noticed in the rectum of the treated larvae but not in the control. Digestive tract developed earlier in treated larvae compared to the control group, such as appearance of tongue, gill raker, fundic, and cardiac stomach development, formation of pharyngeal tooth, and gastric gland. Metamorphosis of Iarvae into juvenile on treated larvae occurred than that the control larvae earlier.
\end{abstract}

KEYWORDS: digestive tract, Epinephelus fuscoguttatus larvae, thyroxine hormone

\section{INTRODUCTION}

Groupers (family Serranidae) are widely distributed in the tropical and subtropical coastal waters. They are one of the most commercially important group of tropical marine fish. Grouper species that have high market value and demand such as Epinephelus coioides, E. malabaricus, E. fuscoguttatus, E. lanceolatus, E. akaara, E. bleekeri, E. awoara, E. areolatus, E. amblycephalus, Plectropomus leopardus, P. maculates, and Cromileptes altivelis (Heemstra \&Randall, 1993).

\begin{abstract}
Marine fish larvae culture largely depends on successful first feeding and normal development and growth of fish larvae. Therefore is important to examine the structural and functional development of the endocrine system during early ontogeny of marine fish larvae. Growth and development in fish, as in all vertebrates, are governed through orderly release of hormones from the neuroendocrine system, which integrates with the environmental, physiological, and genetic information. Many of the developmental processes occurred
\end{abstract}

\# Corresponding author. Research and Development Institute for Mariculture, Jl. Br. Gondol, Kec. Gerokgak, Kab. Buleleng, Kotak Pos 140, Singaraja, Bali 81101, Indonesia. Tel.: +62 36292278 E-mail address: gondolisme@yahoo.com 
during early larval stages of teleost fish, including growth and metamorphosis, are regulated by thyroid hormones, thyroxine or tetraiodothyronine $\left(T_{4}\right)$ and triiodothyronine $\left(T_{3}\right)$ (Eales, 1979; Power et al., 2001; Blanton \& Specker, 2007).

The information on the digestive tract developmental change associated with food assimilation process is crucial for understand the nutritional physiology of fish larvae. This information may help to identify the limiting factors during larval rearing, thus reducing the problem during the weaning process and synchronizing the stage of development with the rearing technology and feeding practices (Hamlin et al., 2000).

The role of thyroxine in teleost larvae's early life and metamorphosis have been proven in the improvement of larvae development, such as Chanos chanos (Lam et al., 1985), Tilapia nilotica (Nacario, 1983), Flounder Paralichfhys olivaceus (Miwa \& Inui, 1987). In the previous study, effect of thyroxine and thiorurea on metamorphosis of coral trout grouper P. leopardus has been studied by Trijuno et al. (2002).

Tiger grouper E. fuscoguttatus aquaculture was established during the past 10 years. Their seed production is still unpredictable and extensively. Average survival to fingerling stage (about $25 \mathrm{~mm}$ in length) was low, generally in the range $0 \% 10 \%$ In addition, survival was highly irregular, one or two larval rearing 'runs' often resulted in reasonable (up to $10 \%$ ) survival, while others had zero survival. Low average survival and unreliable hatchery production were major constraints to the commercialization of grouper larviculture technology (Rimmer, 1997; 1998; Rimmer et al., 2000). Thus this study is to observe the effect of exogenous thyroxine on ontogeny of digestive tract in early life stage of Epinephelus fuscoguttatus.

\section{METHODOLOGY}

\section{Larvae Rearing}

Eggs of E. fuscoguttatus were obtained from natural spawning of a domesticated broodstock. Newly hatched larvae were immersed to exogenous thyroxine (treatment $A=0.1$ $\mathrm{mg} / \mathrm{LT}_{4}$ and treatment $\mathrm{B}=0.2 \mathrm{mg} / \mathrm{L} \mathrm{T}_{4}$ ) for 2 hours in a $30 \mathrm{~L}$ fiberglass tank. The $\mathrm{T}_{4}$ solution was prepared following Lam (1980). For control (treatment C), larvae were not exposed in thyroxine solution. After treatment, larvae were reared in $1 \mathrm{~m}^{3}$ rearing tanks with density $15,000 /$ tank for 40 days rearing periods with gentle aeration. Phytoplankton Nannochloropsis oculata were added daily as water conditioner and as a food for rotifer. Larvae were fed with the rotifer for the first time at $2 \mathrm{DAH}$ (days after hatch). An initial prey concentration is 5 rotifers/ $\mathrm{mL}$ and progressively increases to 30 rotifers $/ \mathrm{mL}$ at $30^{\text {th }} \mathrm{DAH}$. Artificial feed were fed starting at $10 \mathrm{DAH}$ and starting from $20 \mathrm{DAH}$ the larvae were fed with Artemia nauplii. The wastes were siphoned out from the bottom of the rearing tank start from day 7 of the rearing.

\section{Sampling and Analysis}

Twenty samples were collected daily for 10 days and every 3 days until end of the experiment for histology analysis, samples were fixed in Bouin's solution before being preserved in 70\%alcohol and stored at room temperature. Histological studies were then conducted following Kiernan (1990).

Samples for the analysis of total $\mathrm{T}_{4}$ concentration were taken every 5 days until end of the experiment, approximately $50 \mathrm{mg}$ wet weight of larvae (consist of hundreds of larvae) were pooled and frozen at $-70^{\circ} \mathrm{C}$ until analysis. Larvae samples were then homogenized in ice cold $0.01 \mathrm{M}$ Phosphate Buffered Saline (PBS). From this homogenate an aliquot of $25 \mu \mathrm{L}$ was analyzed using an Elisa Kit (Alpha Diagnostic Int. USA).

\section{RESULT AND DISCUSSION}

At $1 \mathrm{DAH}$, the digestive tract of tiger grouper larvae was still closed and just in a form of simple tube (Figure 1). The mouth, buccopharynx, liver, pancreas, and rectum begin to develop at $2 \mathrm{DAH}$ (Figure 2). While the esophagus, stomach, intestines, and anus started to develop at $3 \mathrm{DAH}$. At this age, the digestive tract of larvae treated with and without thyroxin start to discriminate. Several goblet cells were observed in the rectum of treated larvae but absent in the control (Figure 3). Upper and lower teeth of treated larvae at the anterior of the mouth were also observed at this stage. At $4 \mathrm{DAH}$, the yolk completely disappears with gas bladder start to develop and the intestinal valve divided the intestine into midgut and hindgut. Upper teeth, lower teeth and several goblet cells in rectum were observed in control larvae. 


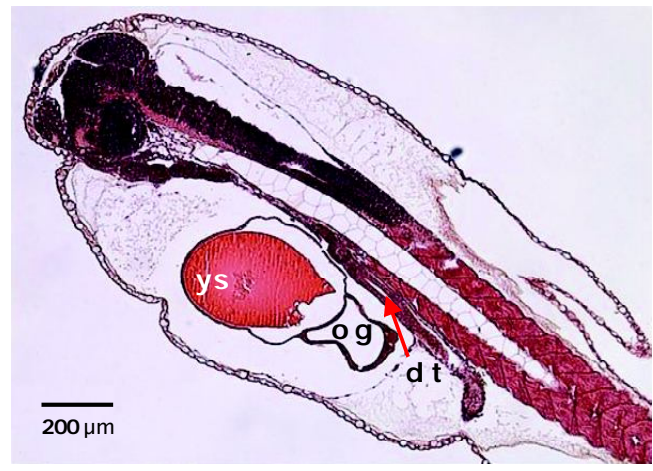

Figure 1. Sagittal section of digestive tract of tiger grouper larvae at 1 DAH. (magnification: 10x; staining: H\&E; dt: digestive tube (arrow); og: oil globule; ys: yolk sac)
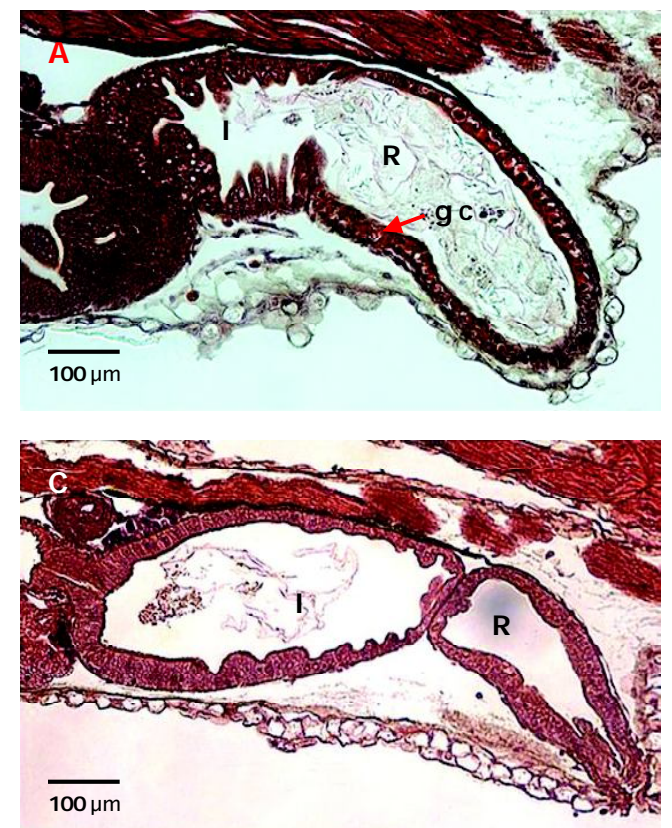

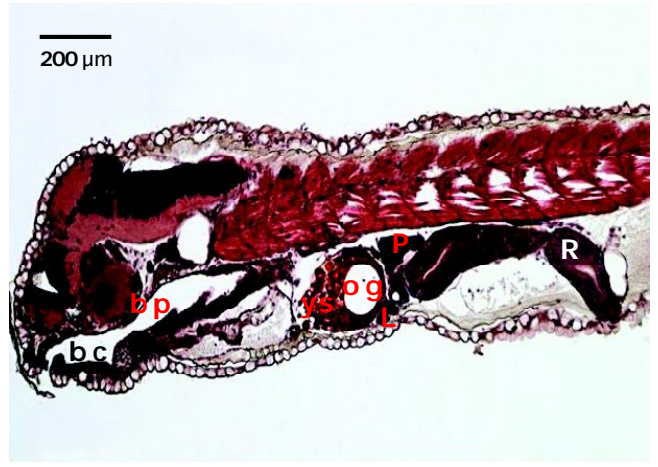

Figure 2. Sagittal section of digestive tract of tiger grouper larvae at $2 \mathrm{DAH}$. (magnification: 10x; staining: $H \& E ; ~ b c:$ buccal cavity; bp: bucopharynx; L: liver; P: pancreas; R: rectum; og: oil globule; ys: yolk sac)

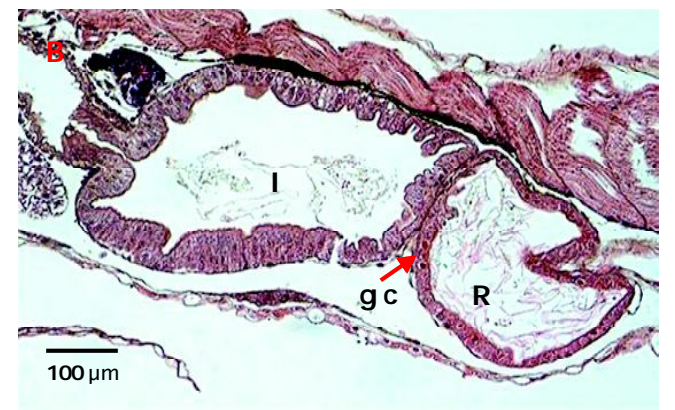

\section{Note:}

A. Larvae treated with $0.1 \mathrm{mg} / \mathrm{L}$ of thyroxine B. Larvae treated with $0.2 \mathrm{mg} / \mathrm{L}$ of thyroxine C. Larvae without thyroxine treatment (control)

Figure 3. Sagittal section of the rectum of tiger grouper larvae 3 at DAH. Note: Several goblet cells were observed in the rectum of treated larvae but absent in the control (magnification: 20x; staining: H\&E; R: rectum; I: Intestine; gc: goblet cell (arrow))

Thyroxine administration on tiger grouper larvae has shown the effects on digestive system development. For larvae treated with 0.2 $\mathrm{mg} / \mathrm{L}$ of $\mathrm{T}_{4}$, the tongue was observed at $5 \mathrm{DAH}$ which is a day earlier compare to other treatment. Gill raker appeared at 6 DAH for larvae treated with $0.2 \mathrm{mg} / \mathrm{L}_{\text {of }} \mathrm{T}_{4}$, at $7 \mathrm{DAH}$ for larvae treated with $0.1 \mathrm{mg} / \mathrm{L} \mathrm{of}_{4}$ and $8 \mathrm{DAH}$ for control groups. Fundic and cardiac stomach were also started to develop at $6 \mathrm{DAH}$ for larvae treated with $\mathrm{T}_{4}$ a day earlier compared than control groups (Figure 4). 

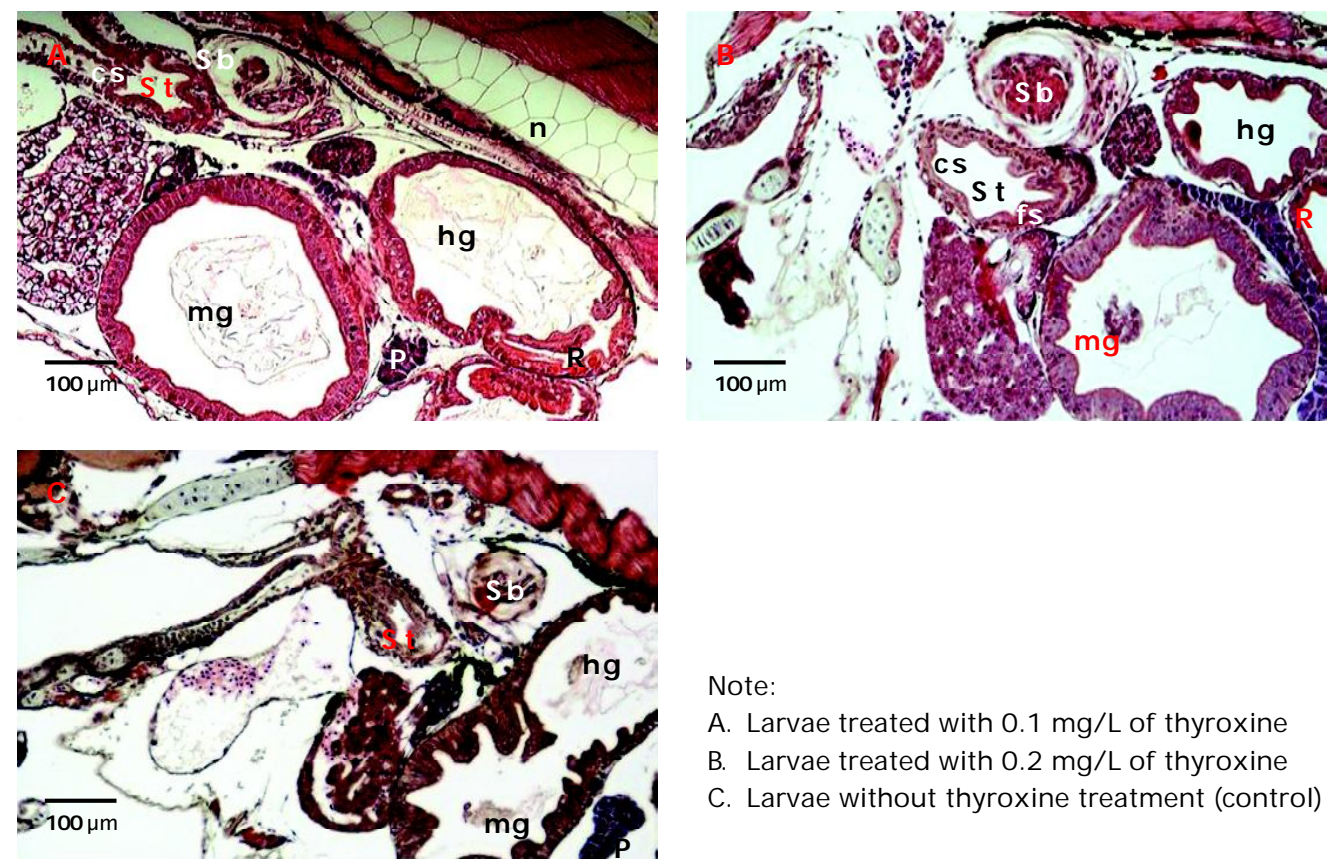

Note:

A. Larvae treated with $0.1 \mathrm{mg} / \mathrm{L}$ of thyroxine

B. Larvae treated with $0.2 \mathrm{mg} / \mathrm{L}$ of thyroxine

C. Larvae without thyroxine treatment (control)

Figure 4. Sagittal section of digestive tract of tiger grouper larvae at 6 DAH. Note: Fundic and cardiac stomach started to develop at $6 \mathrm{DAH}$ a day earlier for treated larvae with $\mathrm{T}_{4}$ than control groups (magnification: 20x; staining: H\&E; CS; cardiac stomach; fs: fundic stomach; hg: hindgut; mg: midgut; L: liver; P: pancreas; R: rectum; sb: swim bladder; St: stomach; n: notochord)

At $8^{\text {th }} \mathrm{DAH}$, taste buds were visible at posterior pharynx in all larvae. At this age, acidophilic supranuclear, and lipid vacuoles observed more in the rectum of larvae treated with thyroxine compared than the control groups (Figure 5).

In larvae treated with exogenous thyroxine, a pharyngeal tooth was found at $10 \mathrm{DAH}$ (Figure 6) and gastric gland had begun to appear at $25 \mathrm{DAH}$ (Figure 7). While in control groups, pharyngeal tooth, and gastric gland was observed at $13 \mathrm{DAH}$ and $28 \mathrm{DAH}$ respectively.

Total $\mathrm{T}_{4}$ concentration showed that larvae immersed with thyroxine have higher concentration than control especially after thyroxine administration and at the end of experiment. From ANOVAs, there are significant differences $(\mathrm{P}<0.05)$ between treatment and control, but there are not significant differences between treatments.

The influence of thyroxine treatment on the development of the digestive organs was observed histologically. At $1 \mathrm{DAH}$, the diges- tive tract of tiger grouper larvae was still closed and just in a form of simple tube. The mouth, buccopharynx, liver, pancreas, and rectum begin to develop at $2 \mathrm{DAH}$. While the esophagus, stomach, intestines, and anus started to develop at $3 \mathrm{DAH}$. These results were similar for all groups of larvae. Previous study on development digestive system in grouper larvae showed similar development, such as in kelp grouper E. bruneus (Kato et al., 2004), dusky grouper E. marginatus (Glamuzina et al., 1998), green grouper E. coioides (Quinitio et al., 2004) and leopard grouper Mycteropterca rosacea (Martinez et al. , 2009). At $3 \mathrm{DAH}$, the digestive tract of larvae treated with and without thyroxin start to discriminate. Several goblet cells were observed in the rectum of treated larvae but absent in the control. Thyroxine administration had positive effects in tiger grouper larvae. Digestive tract develop earlier in treated larvae compared to control group, such as appearance of tongue, gill raker, fundic, and cardiac stomach development, formation of pharyngeal tooth and gastric gland. The pres- 

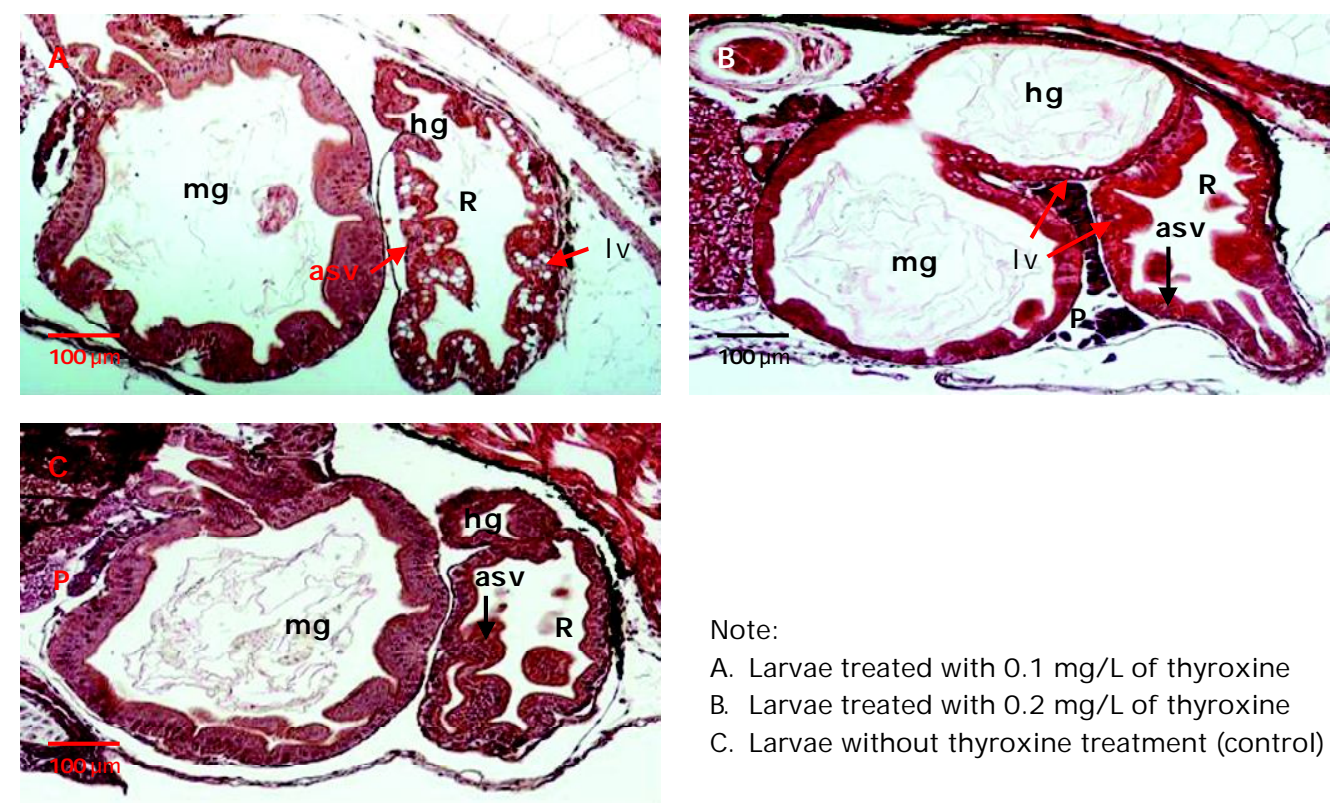

Note:

A. Larvae treated with $0.1 \mathrm{mg} / \mathrm{L}$ of thyroxine

B. Larvae treated with $0.2 \mathrm{mg} / \mathrm{L}$ of thyroxine

C. Larvae without thyroxine treatment (control)

Figure 5. Sagittal section of digestive tract of tiger grouper larvae $8 \mathrm{DAH}$. Note: The rectal epithelium of treated larvae showing lipid vacuoles and acidophilic supranuclear vacuoles, while that of the control was appeared lesser. (magnification: 20x; staining: H\&E; asv: acidophilic supranuclear vacuoles (arrow); hg: hindgut; Iv: lipid vacuoles (arrow); mg: midgut; P: pancreas; R: rectum)
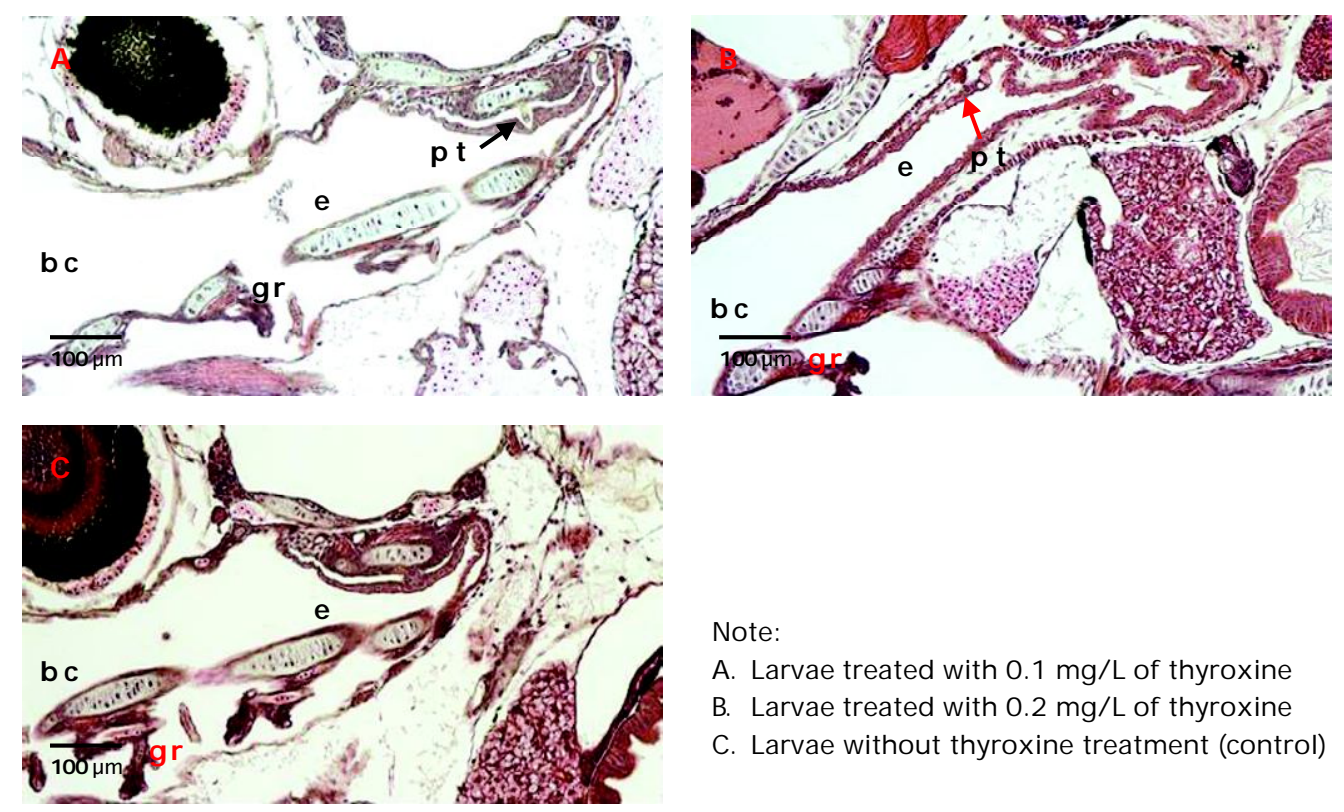

Note:

A. Larvae treated with $0.1 \mathrm{mg} / \mathrm{L}$ of thyroxine

B. Larvae treated with $0.2 \mathrm{mg} / \mathrm{L}$ of thyroxine

C. Larvae without thyroxine treatment (control)

Figure 6. Sagittal section of digestive tract of tiger grouper larvae at $10 \mathrm{DAH}$. Note: Pharyngeal tooth was observed at treated larvae but absent in control at $10 \mathrm{DAH}$, (magnification: 20x; staining: H\&E; bc: buccal cavity; e: esophagus; gr: gill raker; pt: pharyngeal tooth (arrow)) 

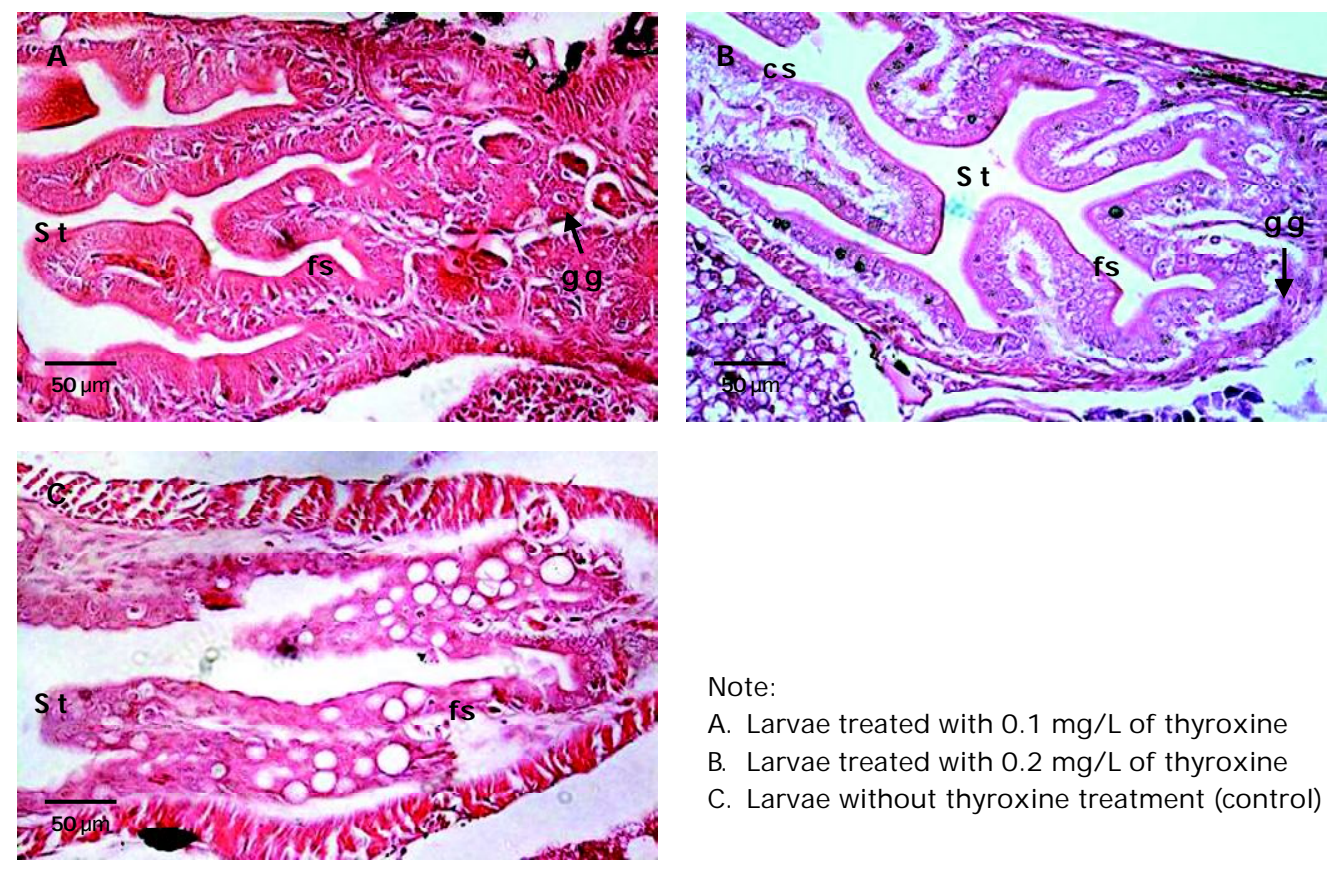

Note:

A. Larvae treated with $0.1 \mathrm{mg} / \mathrm{L}$ of thyroxine

B. Larvae treated with $0.2 \mathrm{mg} / \mathrm{L}$ of thyroxine

C. Larvae without thyroxine treatment (control)

Figure 7. Sagittal section of the stomach of tiger grouper larvae at $25 \mathrm{DAH}$. Note: The gastric gland of treated larvae was observed earlier than control, (magnification: 40x; staining: H\&E; cs: cardiac stomach; fs: fundic stomach; gg: gastric gland (arrow); St: stomach)

ence of acidophilic supranuclear and lipid vacuoles observed more at the rectum of treated larvae; this indicated increasing of digestive activity in larvae treated with thyroxine than control. Tanaka et al., 1995 demonstrated that treatment of larvae with thyroid hormones may be beneficial as $T_{4}$ appears to stimulate the uptake of both proteins and fats in the digestive tract. The most prominent means of nutrient uptake in larval fish appears to be intact protein ingestion by pinocytosis in the rectal epithelium (Iwai \& Tanaka, 1968; Watanabe, 1984), which may be stimulated by exogenous $\mathrm{T}_{4}$. The presence of acidophilic supranuclear vacuoles was result of pinocytosis of protein and presence of lipid vacuoles confirmed fat absorption. Pynocitosis and intracellular digestion have been suggested as the main mechanism for protein absorption in teleost larvae during the absence of a functional stomach (Boulhic \& Gabaudan, 1992; Gisbert et al., 2004; Sarasquete et al., 1995). Kim \& Brown (1997) described the regulatory hormone (such as thyroid hormone) could precondition the digestive tract of larvae for increased digestion and nutrient absorption.
In treated larvae gastric gland had begun to appear at $25 \mathrm{DAH}$, while in control groups gastric gland was observed at $28 \mathrm{DAH}$. Miwa et al. (1992) demonstrated that thyroid hormone stimulates gastric development during metamorphosis of Japanese flounder. The end of larval stage when all fins are fully developed, the scales and most organs have formed (Balon, 1975). However, based on digestive organ development, the larvae stage end when gastric gland formed (Boulhic \& Gabaudan, 1992; Bisbal \& Bengston, 1995; Liem, 2001) and stomach was the last organ of digestive system to differentiate (Gisbert et al., 2004). The first appearance of gastric gland among teleost is variable depend on fish species. In milkfish Chanos chanos it occurred at 42 DAH (Ferraris et al., 1987). In dover sole Solea solea, it occurred at 22 DAH (Boulhic \& Gabaudan, 1992). In Siberian sturgeon the appearance of gastric glands occurred earlier at 9 DAH (Gisbert et al., 1998). The gastric gland differentiation indicated metamorphosis occurring, generally concurrent with the transition from larval to juvenile. Because the fully functional stomach is thought to increase digestive capacity of 
Table 1. The concentration of total $T_{4}$ in treated larvae and control

\begin{tabular}{lc}
\hline & $\begin{array}{c}\text { Means of } \mathbf{~ T}_{\mathbf{4}} \text { level } \\
\left(\boldsymbol{\mu} \mathbf{g} \mathbf{~ d L}^{-1} \mathbf{)}\right.\end{array}$ \\
\hline A. $(0.1 \mathrm{mg} / \mathrm{L})$ & $1.54 \pm 0.058^{\mathrm{a}}$ \\
B. $(0.2 \mathrm{mg} / \mathrm{L})$ & $1.53 \pm 0.070^{\mathrm{a}}$ \\
C. $(0 \mathrm{mg} / \mathrm{L})$ & $1.49 \pm 0.040^{\mathrm{b}}$ \\
\hline Note: ab the different superscript letters was \\
significantly different in $\mathrm{P}<0.05$
\end{tabular}

the gastrointestinal system and to be an important contributor to the high growth rate exhibited by newly metamorphosed juvenile (Tanaka, 1973 in Soffientino \& Specker, 2003).

The measurement of total $\mathrm{T}_{4}$ in tiger grouper larvae showed that larvae immersed with thyroxine have higher concentration than control especially after thyroxine administration and at the end of experiment. Abol- Munafi et al. (2005) suggested that the positive effect of exogenous thyroxine in enhancement of $\mathrm{T}_{4}$ level, particularly in early life stage of marble goby Oxyeleotris marmoratus. Miwa \& Inui (1985) also showed that $\mathrm{T}_{4}$ administration has successfully increased plasma $\mathrm{T}_{4}$ levels and caused body silvering of Amago Salmon (Oncorhynchus rhodurus). While Eales (1979) described that exogenous $\mathrm{T}_{4}$ treatment would increase $\mathrm{T}_{4}$ level in plasma, therefore decreased endogenous TSH secretion, and then resulting decrease in endogenous secretion. The changes of hormonal level are related to response and ability of the embryo or larvae to control the circulating TH levels (Balon, 1975). Moreover, in fresh water fishes the iodine uptake was easier compare to marine fishes, particularly in iodine less environment (Lam, 1995).

\section{REFERENCES}

Munafi, A.A.B., Asmanelli, Effendi, A.M.W., \&Soh, A.A. 2005. Effect of Exogenous Thyroxine on Morphology and Development of Thyroid Gland in Marble Goby Oxyeleotris marmoratus Bleeker Larvae. Journal of Animal and Veterinary Advances, 4(7): 624629.

Balon, E.K. 1975. Terminology of intervals in fish development. J. Fish. Res. Board Can., 32: 1,663-1,670.
Bisbal, G.A. \& Bengston, D.A. 1995. Development of the digestive tract in larval summer flounder. North American Journal of Aquaculture, 61(3): 239- 242.

Blanton, M.L. \& Specker, J.L. 2007. The hypothalamic- pituitary- thyroid (HPT) axis in fish and its role in fish development and reproduction. Crit. Rev. Toxicol., 37: 97- 115.

Boulhic, M. \& Gabaudan, J. 1992. Histological study of the organogenesis of the digestive system and swim bladder of the Dover sole Solea solea. Aquaculture, 102: 373- 396.

Eales, J.G. 1979. Thyroid functions in cyclostomes and fishes. In Barrington, E.J.W. (Ed.), Hormones and Evolution. Academic Press, New York, p. 341- 436.

Ferraris, R.P., Tan, J.D., \& de La Cruz, M.C. 1987. Development of digestive tract of milkfish. Chanos chanos (Forskal): Histology and Histochemistry. Aquaculture, 61: 241- 257.

Gisbert, E., Piedrahita, R.H., \&Conklin, D.E. 2004. Ontogenetic development of the digestive system in California halibut (Paralichthys californicus) with notes on feeding practices. Aquaculture, 232: 455- 470.

Glamuzina, B., Skaramuca, B., Glavik, N., Kazul, V., Dulcic, J., \& Kraljevic. M. 1998. Egg and Early development of laboratory reared dusky grouper, Epinephelus marginatus (Lowe 1834) Pisces, Serranidae. Scientia Marina, 62(4): 373- 378.

Hamlin, H.J., von Herbing, I.H., \&Kling, L.J. 2000. Histological and morphological evaluations of the digestive tract and associated organs of haddock throughout post- hatching ontogeny. J. Fish Biol., 57: 716- 732.

Heemstra, P.C. \& Randall, J.E. 1993. Groupers of the World, FAO Species Catalogue. Rome, FAO. FAO Fish Synop., 125 (16): 382.

Iwai, T. \& Tanaka, M. 1968. The comparative study of the digestive tract of teleost larvae- III. Epithelial cells in the posterior gut of halfbeak larvae. Bulletin Japan Society and Science Fishes, 34: 44- 48.

Kato, K., Ishimaru, K., Sawada, Y. Mutsuro, J. Miyashita, S., Murata, O., \& Kumai, H. 2004. Ontogeny of digestive and immune system organs of larval and juvenile kelp grouper Epinphelus bruneus reared in the laboratory. Fisheries Science, 70: 1,061- 1,069.

Kiernan, J.A. 1980. Histological and Histochemical Methods Theory and Practise. $2^{\text {nd }}$ Ed., Pergamon Press. 
Kim, B.G. \& Brown, C.L. 1997. Interaction of cortisol and thyroid hormone in the development of Pacific treadfin. American Zoologist, 37: 470- 481.

Lam, T.J. 1980. Thyroxine Enhances Larval Development and Survival in Sarotherodon Tilapia Mossambicus Ruppell. Aquaculture, 21:287- 291.

Lam, T.J. 1995. Possible rules of hormones in the control of eggs overripening and embryonic and larval development in fish. Proceedings of International Symposium on Biotechnology. Aplication in Aquaculture. Asian Fisheries Society Special. Publication, 10: 29- 39.

Lam, T.J., Juario, J.V., \& Banno, J. 1985. Effect of thyroxine on growth and development in post yolk sac larvae of milk fish, Chanos chanos. Aquaculture, 46: 174- 184.

Liem, P.T. 2001. Studies on early development and larval rearing Oxyeleotris marmoratus (Bleeker). Thesis submitted in fulfillment of the requirements for the degree of Master of Science in the Faculty of Science and Technology. University Putra Malaysia Terengganu. March, 2001.

Martinez, L.R. \&Gracia, L.V. 2009. Morphological development and growth pattern of the leopard grouper Myctereoperca rosacea during larval development. Aquaculture Research, 41: 120- 128.

Miwa, S. \& Inui, Y. 1985. Effects of L- Thyroxine and Ovine Growth Hormone on Smoltification of Amago Salmon (Oncorhynchus rhodurus). General and Comparative Endocrinology, 58: 436- 442.

Miwa, S. \& Inui, Y. 1987. Effects of Various Doses of Thyroxine and Triiodothyronine on the Metamorphosis of Flounder (Paralichfhys olivaceus). General And Comparative Endocrinology, 67: 356- 363.

Miwa, S., Yamano, K., \& Inui, Y. 1992. Thyroid hormone stimulates gastric development in flounder larvae during metamorphosis. Journal of Experimental Zoology, 261: 424430.

Nacario, F.J. 1983. The effect of thyroxine on the larvae and fry of Sarotherodon niloticus I. (Tilapia nilotica). Aquaculture, 34: 73- 83.

Power, D.M., Llewellyn, L., Faustino, M., Nowell, M.A., Bjornsson, B.T., Einarsdottir, I.E.,
Canario, A.V.M., \&Sweeney, G.E. 2001. Thyroid hormones in growth and development of fish. Comp. Biochem. Physiol., 130: 447459.

Quintinito, G.F., Sa- an, A.C., Toledo, J.D., \&Tan fermin, J.D. 2004. Changes in the gastrointestinal tract and associated organ during early development of the grouper (Epinephelus coioides). Advance in grouper aquaculture: Australian Center for International Agriculture Research, Canberra, p. 28-29.

Rimmer, M. 1997. Marine finfish aquaculture in Taiwan. Australia Aquaculture, 11: 37- 41.

Rimmer, M. 1998. Grouper and snapper aquaculture in Taiwan. Australia Aquaculture, 12: 3- 7.

Rimmer, M.A., Williams, K.C., \& Phillips, M.J. 2000. Proceedings of the Grouper Aquaculture Workshop held in Bangkok, Thailand, 7-8 April 1998, Network of Aquaculture Centres in Asia- Pacific, Bangkok, Thailand.

Sarasquete, M.C., Polo, A., \& Yufera, M. 1995. Histology and histochemistry of the development of the digestive system of larval gilthead seabream, Sparus aurata L. Aquaculture, 130: 79- 92.

Soffientino, B. \& Specker, J.L. 2003. Age- dependent changes in the reponse of the stomach to thyroidal signaling in developmentally arrested larval summer flounder. General and Comparative Endocrinology, 134: 237- 243.

Tanaka, M., Tanangonan, J.B., Tagawa, M., de Jesus, E.G., Nishida, H., Isaka, M., Kimura, R., \& Hirano, T. 1995. Development of the pituitary, thyroid, and interregnal glands and application of endocrinology to the improved rearing of marine fish larvae. Aquaculture, 135: 111- 126.

Trijuno, D.D., Yoseda, K., Hirokawa, J., Tagawa, M., \& Tanaka, M. 2002. Effects of thyroxine and thiourea on the metamorphosis of coral trout grouper Plectropomus leopardus. Fisheries Science, 68: 282- 289.

Watanabe, Y. 1984. Morphological and fungsional changes in rectal epithelium cells of pond smelt during post embryonic development. Bull. Jpn. Soc. Sci. Fish, 50: 805- 814. 